\title{
Mapping irrigation potential from renewable groundwater in Africa - a quantitative hydrological approach
}

\author{
Y. Altchenko ${ }^{1,2,3}$ and K. G. Villholth ${ }^{1}$ \\ ${ }^{1}$ International Water Management Institute, Pretoria, South Africa \\ ${ }^{2}$ Ministère de l'Agriculture, de l'Agroalimentaire et de la Forêt, Paris, France \\ ${ }^{3}$ Laboratoire METIS, UMR 7619 UPMC/CNRS, Université Pierre et Marie Curie, Paris, France \\ Correspondence to: Y. Altchenko (y.altchenko@cgiar.org)
}

Received: 15 April 2014 - Published in Hydrol. Earth Syst. Sci. Discuss.: 10 June 2014

Revised: 3 October 2014 - Accepted: 29 October 2014 - Published: 26 February 2015

\begin{abstract}
Groundwater provides an important buffer to climate variability in Africa. Yet, groundwater irrigation contributes only a relatively small share of cultivated land, approximately $1 \%$ (about $2 \times 10^{6}$ hectares) as compared to $14 \%$ in Asia. While groundwater is over-exploited for irrigation in many parts in Asia, previous assessments indicate an underutilized potential in parts of Africa. As opposed to previous country-based estimates, this paper derives a continentwide, distributed $\left(0.5^{\circ}\right.$ spatial resolution $)$ map of groundwater irrigation potential, indicated in terms of fractions of cropland potentially irrigable with renewable groundwater. The method builds on an annual groundwater balance approach using 41 years of hydrological data, allocating only that fraction of groundwater recharge that is in excess after satisfying other present human needs and environmental requirements, while disregarding socio-economic and physical constraints in access to the resource. Due to high uncertainty of groundwater environmental needs, three scenarios, leaving 30,50 and $70 \%$ of recharge for the environment, were implemented. Current dominating crops and cropping rotations and associated irrigation requirements in a zonal approach were applied in order to convert recharge excess to potential irrigated cropland. Results show an inhomogeneously distributed groundwater irrigation potential across the continent, even within individual countries, mainly reflecting recharge patterns and presence or absence of cultivated cropland. Results further show that average annual renewable groundwater availability for irrigation ranges from 692 to $1644 \mathrm{~km}^{3} \mathrm{de}$ pending on scenario. The total area of cropland irrigable with renewable groundwater ranges from 44.6 to $105.3 \times 10^{6}$ ha, corresponding to 20.5 to $48.6 \%$ of the cropland over the con-
\end{abstract}

tinent. In particular, significant potential exists in the semiarid Sahel and eastern African regions which could support poverty alleviation if developed sustainably and equitably. The map is a first assessment that needs to be complimented with assessment of other factors, e.g. hydrogeological conditions, groundwater accessibility, soils, and socio-economic factors as well as more local assessments.

\section{Introduction}

Irrigation expansion is seen as a significant leverage to food security, livelihoods, rural development, and agricultural and broader economic development in Africa, especially in subSaharan Africa (SSA). National and regional (CAADP, 2009; NEPAD, 2003) policies and plans stress irrigation development, and more broadly sustainable land and water management, as a key component to poverty alleviation and gains in food productivity.

FAO (2005) assessed the potential for irrigation development ${ }^{1}$ in Africa to be $42.5 \times 10^{6}$ ha, corresponding to $20.1 \%$ of the cultivated area or $5.7 \%$ of the cultivable land. While still playing a secondary and minor role in national and re-

\footnotetext{
${ }^{1}$ Definition of irrigation potential in FAO (2005): area of land (ha) which is potentially irrigable. Country/regional studies assess this value according to different methods - for example some consider only land resources suitable for irrigation, others consider land resources plus water availability, and others include in their assessment economic aspects (such as distance and/or difference in elevation between the suitable land and the available water) or environmental aspects, and so forth.
} 
gional plans, groundwater is increasingly included as a viable and suitable supplementary or sole source to develop for irrigation along with traditional surface water resources (MoAC, 2004; MoFA and GIDA ${ }^{2}$, 2011; MoFED, 2010; MoIWD, 2005; MoWEA, 2013). This is explained by evidence that farmers progressively embrace groundwater irrigation (GWI) spontaneously and with own investments where conditions permit (Villholth, 2013) and the notion that the groundwater resources in Africa generally are plentiful as well as underutilized (MacDonald et al., 2012).

Groundwater irrigation presently covers around $2 \times 10^{6}$ ha in Africa, equivalent to $1 \%$ of the cultivated land ${ }^{3}$ (Siebert et al., 2010). In Asia, similar figures amount to $38 \times 10^{6}$ ha or $14 \%$ of cultivated land (Siebert et al., 2010). Hence, it is fair to assume that there is appreciable scope for further developing GWI in the continent. Barriers to an expansion of groundwater-based irrigation in Africa, and in particular SSA, include lack of knowledge of the resource and best options for sustainable development. So, while present levels of development are comparatively low and most development occurs in the informal sector (Villholth, 2013), progress towards greater and long-term benefits need to be informed by estimations of upper limits for sustainable development and most appropriate geographic areas for development. The need for qualified estimates of groundwater irrigation potential (GWIP) is recognized at the national (MoFA and GIDA, 2011; Awulachew et al., 2010) as well as regional scale (MacDonald et al., 2012). Qualitative, relative groundwater potential was mapped for Ethiopia by MacDonald et al. (2001), however, with no specific focus on the potential for irrigation. You et al. (2010) estimated the potential contribution from small-scale irrigation (including ponds, small reservoirs, rainwater harvesting, and groundwater) in Africa to be 0.3 to $16 \times 10^{6}$ ha based on a continental distributed mainly economic multi-criteria analysis at a $5 \mathrm{~min}$. resolution. Pavelic et al. $(2012,2013)$ afforded a relatively simple water balance approach to provide country or catchment scale estimates, respectively, of gross GWIP in terms of irrigable cropland, taking into consideration the crop irrigation water needs and disregarding existing irrigation development. Water available for irrigation was constrained by renewable groundwater resources, priority demands from domestic, livestock, industrial uses as well as environmental requirements. They determined the GWIP of 13 semi-arid countries in SSA to be in the range of $13.5 \pm 6.0 \times 10^{6}$ ha, or between $0.1-3.9 \times 10^{6}$ ha per country. While the previous estimations of GWIP in Africa were continental (You et al., 2010), national (Pavelic et al., 2013), or sub-national (Pavelic

\footnotetext{
${ }^{2}$ In the Ghana National Irrigation Policy, groundwater irrigation falls under the category "informal irrigation".

${ }^{3}$ Cultivated land and cropland are here used interchangeably, to mean the combined arable land area and the area under permanent crops (http://www.fao.org/nr/water/aquastat/data/glossary/ search.html?lang=en).
}

et al., 2012) in scope, the present paper builds on the latter approach providing a fully distributed and consistent assessment of the gross GWIP for the entire continent at a grid scale of $0.5^{\circ}$. The concept of the approach is to map crop area that can be irrigated with locally renewable groundwater resources at a continental and distributed scale. By doing so, regional differences across the continent become conspicuous and variability within the countries also becomes apparent. The extent and distribution of GWIP is subsequently compared with the existing GWI extent and distribution across Africa to determine net GWIP, i.e. areas and regions with high and low residual GWIP. Finally, the limitations and uncertainties related to the methodology are assessed and discussed.

\section{Methodology}

Following the approach of Pavelic et al. (2013), the methodology assumes groundwater as the sole source of irrigation water and hence gives an estimate of the area that could potentially be irrigated by groundwater disregarding any existing irrigation, whether from groundwater or surface water. Importantly, the method considers sustainable GWI from a resource perspective, i.e. the use of only renewable groundwater for human needs (including irrigation) while partially satisfying environmental requirements from this renewable resource. As a consequence, non-renewable (fossil) groundwater is not considered available, preventing longterm aquifer depletion.

The water balance assessment is based on a GIS analysis and mapping with a final resolution of $0.5^{\circ}$ assuming each cell (about $50 \mathrm{~km} \times 50 \mathrm{~km}$ ) to be homogeneous and independent of other cells, i.e. no lateral groundwater or irrigation water flows occur between cells. For each cell, the GWIP $\left[\mathrm{L}^{2}\right]$ is calculated as the potential cropland area that the available groundwater resource can irrigate (Supplement):

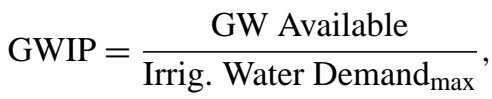

where groundwater availability $\left[\mathrm{L}^{3} \mathrm{~T}^{-1}\right]$ is calculated as any excess of groundwater recharge, considering other groundwater demands from humans (domestic uses, livestock, industry) and the environment:

$$
\begin{aligned}
\text { GW Available } & =\text { GW Recharge }- \text { Human GW Demand } \\
& - \text { Environ. GW Req. }
\end{aligned}
$$

The gross irrigation water demand $\left[\mathrm{L} \mathrm{T}^{-1}\right]$, which represents the groundwater abstraction needed to satisfy the deficit rain- 
fall and the irrigation losses, is determined by

Irrig. Water Demand

$=\frac{\left\{\sum_{i=1}^{n}\left(\left[\sum_{j=1}^{m}(\text { Crop Water Demand }- \text { Green Water })_{j}\right] \times[\% \text { of Area }]_{i}\right)\right\}}{\text { Irrig. Efficiency }}$.

The crop water demand $\left[\mathrm{L} \mathrm{T}^{-1}\right]$, which represent the monthly amount of water needed by the crop to grow optimally during the months of its growing period, independently of the water source and considering water as the only limiting factor for optimal growth (FAO, 1986), is determined by:

Crop Water Demand De $_{j}=K_{\mathrm{c}} \times E_{0, \max _{j}}$.

The equation parameters are given as follows:

- $E_{0, \max }[\mathrm{L}]$ is the maximum reference evapotranspiration for each calendar month.

- $K_{\mathrm{c}}[-]$ is the crop coefficient.

- Green Water $\left[\mathrm{L} \mathrm{T}^{-1}\right]$ is the water available for plants naturally and indirectly from the rainfall through soil moisture.

- \% of Area [-] is the areal fraction of a specific crop relative to the total crop area within a grid cell.

$-n[-]$ is the number of crops grown within the grid cell.

- $m[-]$ is the number of months of the year (12).

- Irrig. Efficiency [-] is the irrigation efficiency coefficient. It is used to express the fraction of groundwater abstracted that is not lost along the water transport from the abstraction point to the crop (FAO, 1989). The extracted groundwater quantity does not reach fully the crops because of transport losses or losses in the field.

- GW Recharge $\left[\mathrm{L}^{3} \mathrm{~T}^{-1}\right]$ is the net groundwater recharge. It corresponds to the total quantity of water from rainfall which reaches the aquifer as diffuse recharge. Return flows from surface water irrigation and other forms of artificial recharge as well as focused or induced recharge from water surface bodies are disregarded.

- Human GW Demand $\left[\mathrm{L}^{3} \mathrm{~T}^{-1}\right]$ is the groundwater use for anthropogenic activities, such as domestic and industrial water supply and livestock watering. Domestic and industrial water requirement are assumed to come partly from groundwater while livestock watering is assumed to be fully supplied by groundwater (see also Sect. 3.3).

- Environ. GW Req. $\left[\mathrm{L}^{3} \mathrm{~T}^{-1}\right]$ is the quantity of water coming from groundwater, which is directly linked to the environment for maintaining ecosystems. This includes river baseflow and groundwater influx to wetlands.
The proposed approach, taking annual water balances, yields an estimate of GWIP with respect to historic hydrology when considering the assessment over a number of years with varying rainfall and recharge over the continent. This is described in more detail in the next section.

\section{Data sources and preparation}

\subsection{Hydrological data}

Data on recharge (GW Recharge, Eq. 2) and green water (Green Water, Eq. 3) derive from model outputs from the PCR-GLOBWB global hydrological model (Van Beek et al., 2011; Wada et al., 2011). Data for Africa from a global simulation with $0.5^{\circ}$ spatial resolution for a recent 41 -year period (January 1960 to December 2000) have been used (including Madagascar, but excluding the smaller islands of Comoros, Mauritius, Seychelles and Cape Verde). The model calculates for daily time steps the water storage in two vertically stacked soil layers and an underlying groundwater layer, as well as the water exchange between the layers and between the top layer and the atmosphere (rainfall, evaporation and snow melt). The model also calculates canopy interception and snow storage. During the simulation period, land cover changes are not taken into consideration. For the green water availability, the sum of the simulated actual transpiration of the two soil layers under non-irrigation conditions (i.e. natural vegetation and rainfed crops) was used (Van Beek et al., 2011). This conservative approach, effectively reducing precipitation for surface runoff, percolation, soil evaporation and interception, gives a measure of easily available soil moisture for the plants, and ensures that the availability of water for the crops is not overestimated. This approach is in agreement with the green water definition by Savenije (2004) and the productive green water definition by Falkenmark and Rockström (2006), who define transpiration as the productive component of the green water, which is involved in biomass production in terrestrial ecosystems as opposed to the unproductive part attributable to soil evaporation (Supplement).

\subsection{Crop and irrigation data}

The necessary crop data to calculate irrigation water demand (Irrig. Water Demand, Eq. 3) relate to the crop distribution across the continent, the crop calendar over the year, encompassing one or a maximum of two crops per year for any area, and the annually accumulated monthly crop water demand for each crop in each cell. For the crop distribution, data for the 2000 crop distribution have been used (Monfreda et al., 2008; Ramaunkutty et al., 2008). Figure 1 shows the cropland $\left(217 \times 10^{6} \mathrm{ha}\right)$ distribution in Africa. This includes the cultivated (i.e. harvested) cropland and non-cultivated cropland in 2000.

Six major irrigated crop groups, accounting for an average of $84 \%$ of the total harvested cropland in 2000 


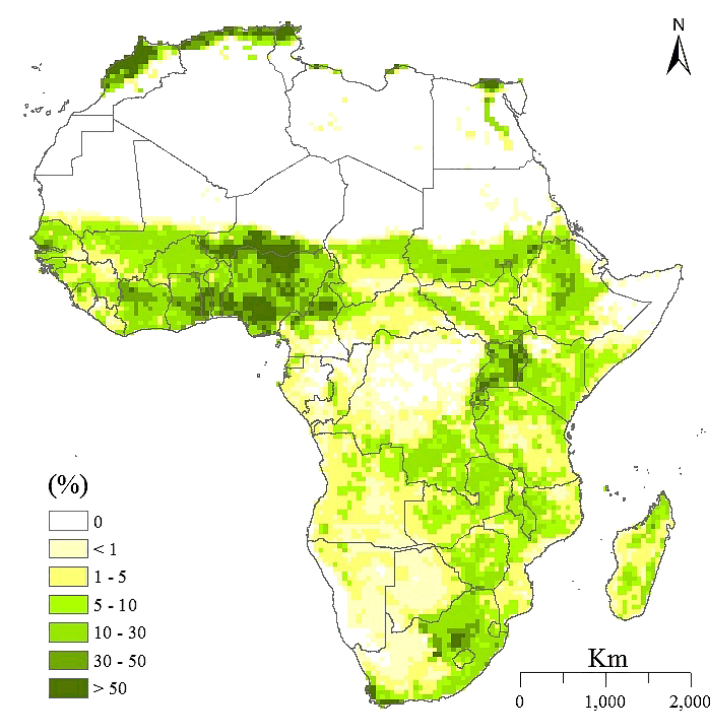

Figure 1. Proportion of cropland per cell $(0.5 \times 0.5$ degree $)$ in 2000 (Ramankutty et al., 2008).

$\left(165.7 \times 10^{6}\right.$ ha) over the continent, were considered (Table 1).

These include: cereals, oil crops, roots, pulses, vegetables and sugar crops (sugarcane mostly in Africa). The proportion of the land area occupied by the different crop groups is shown in Fig. 2. It is assumed that the cropping pattern is not influenced by introduction of groundwater. While it is known that smallholder GWI may preferentially be applied to higher value crops (like vegetables) in SSA (Villholth, 2013) and that the dominant crops in irrigated and rainfed agriculture differ from region to region in Africa (Portmann et al., 2010), no data on the larger scale and distributed impact of crop pattern change as a result of GWI exist.

In certain areas, the aggregated crop group areas accounted for more than $84 \%$ of the harvested cropland. This is because double cropping occurs. Hence, in order to ensure that double cropping does not entail exaggerated cropland areas, the crop group areas were downscaled by cell-by-cell factors, making the aggregated crop group area for those cells equal to $84 \%$ of the harvested cropland.

For the crop calendar, Africa can be divided into 23 irrigation cropping pattern zones, within which crop calendar, irrigation method and cropping intensity can be assumed to be homogeneous within the cropland (FAO, 1997) (Fig. 3). This subdivision is applied in this study.

The crop calendar data have been extracted from the FAO crop calendar ${ }^{4}$ and other sources (FAO, 1992, 1986) and compiled into a calendar per crop group done for each irrigation cropping pattern zone. The calendar indicates the specific crops present in the group for each irrigation cropping pattern zone (Supplement). Up to two specific crops from the

\footnotetext{
${ }^{4}$ http://www.fao.org/agriculture/seed/cropcalendar/welcome.do (last access: 31 March 2014).
}

Table 1. Areal proportion of crop groups cultivated in Africa for the year 2000, adapted from Monfreda et al. (2008).

\begin{tabular}{lrr}
\hline Type of crop & Area $\left(10^{6}\right.$ ha $)$ & Proportion $(\%)$ \\
\hline Cereals & 79.4 & 47.92 \\
Oils & 19.6 & 11.83 \\
Roots & 17.8 & 10.74 \\
Pulses & 16.3 & 9.84 \\
Vegetables & 4.4 & 2.66 \\
Sugar crops & 1.4 & 0.84 \\
Fruit & 8.4 & 5.07 \\
Forage & 3.7 & 2.23 \\
Fiber & 4.2 & 2.53 \\
Tree nuts & 1.3 & 0.78 \\
Other crops & 9.2 & 5.56 \\
\hline Total & 165.7 & $100 \%$ \\
\hline
\end{tabular}

same crop group can be cultivated per year on the same cropland and allows year-round cropping and an annual cropping rotation.

The monthly crop water demand for each crop group is determined by Eq. (4), using the maximum monthly reference evapotranspiration for each calendar month over the period 1960-2000 and crop coefficient $\left(K_{\mathrm{c}}\right)$ as determined in the Supplement. Growth periods and corresponding Kc values for the various crops are extracted from the literature (FAO, 1992, 1986) and are assumed to be constant over the 41-year period while the reference evapotranspiration data are extracted from inputs to the PCR-GLOBWB global hydrological model. Since the crop calendar includes entries with more than one specific crop for a crop group (e.g. millet/wheat for cereals) and they have similar, but not equal monthly water demands (Supplement), a conservative approach is applied, whereby the larger figure for the crops has been applied, unless the difference between them is equal to or more than 0.05 and 0.1 , in which case the larger coefficient is reduced by 0.01 or 0.02 , respectively. The reason for applying the conservative approach is to ensure that the GWIP is not overestimated.

The irrigation efficiency (Irrig. Efficiency, Eq. 3) takes into consideration the water lost during the irrigation path from the water abstraction point to the water reaching the plants. Water losses occur mainly during water transport (i.e. pipe leakage or evaporation/leakage in open canals) and in the field (i.e. water running off the surface or percolating past the root zone). Each irrigation cropping pattern zone has an irrigation efficiency coefficient based on figures found in the literature, type of crops irrigated and intensification level of the irrigation techniques (FAO, 1997) (Table 2). The coefficient is mainly based on surface water irrigation and it is here assumed applicable to GWI. This assumption implies a conservative estimate of GWIP as open canal water transport from rivers or lakes is typically found to be less efficient 

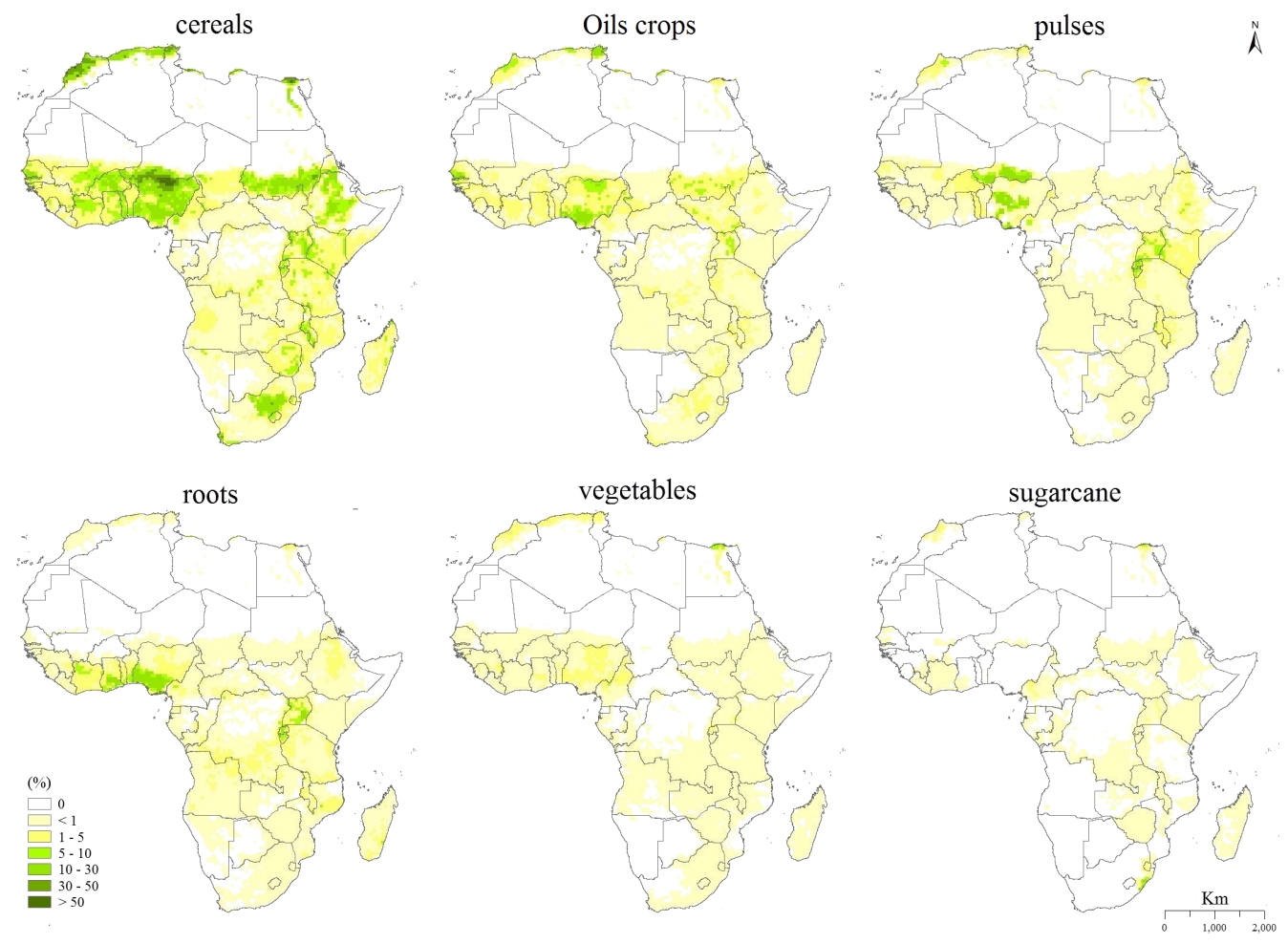

Figure 2. Proportion of crop group area per cell $\left(0.5^{\circ} \times 0.5^{\circ}\right)$ cultivated in 2000 of the six largest crop groups (adapted from Ramankutty et al., 2008).

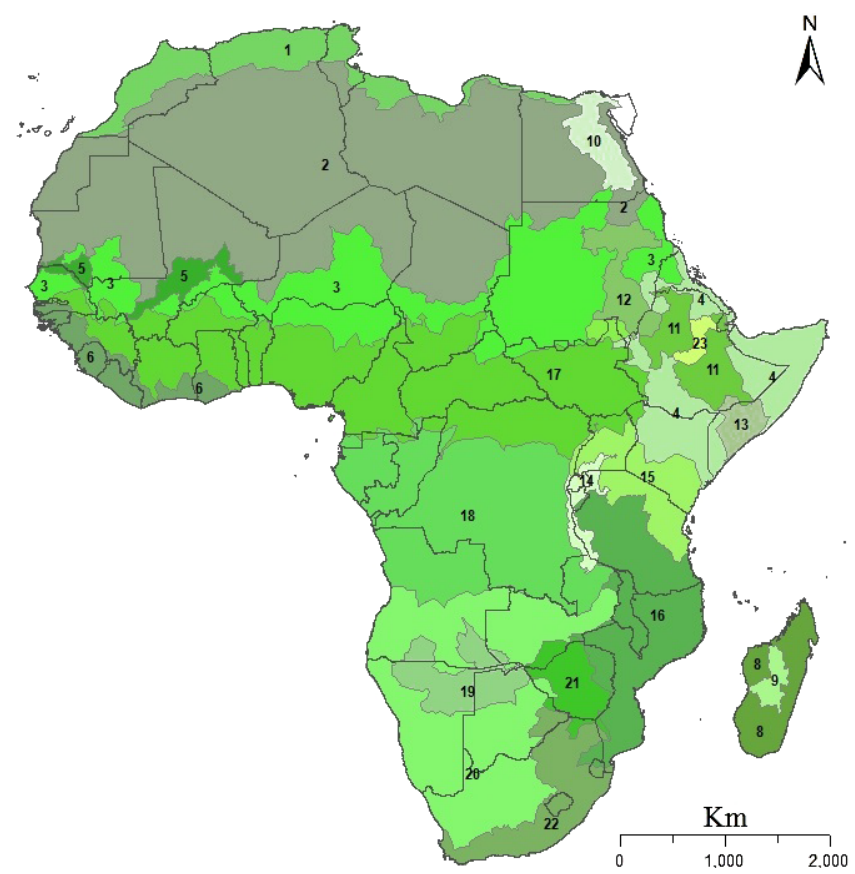

Figure 3. Delineation of the 23 irrigation cropping pattern zones in Africa (based on FAO, 1997; http://www.fao.org/geonetwork/srv/ en/main.home, last access: 1 April 2014). than groundwater, which is abstracted more locally and in a distributed fashion (Foster and Perry, 2010).

\subsection{Other groundwater uses}

Irrigation is only one of the groundwater uses and it is necessary to take into account the other anthropogenic and environmental groundwater uses. They are divided into four categories: domestic, industrial, and livestock demands as well as environmental requirements. Irrigation from groundwater is possible only after the groundwater demands of these uses have been satisfied.

Groundwater demand of anthropogenic activities is calculated for each cell using the density map of population and livestock from 2000 (FAO, 2007a, b) and data in Table 3. Domestic, industrial and livestock water demand is assumed constant over the period 1960-2000.

The environmental groundwater requirement remains highly uncertain. To account for this, three scenarios have been applied: with environmental groundwater requirements representing $70 \%$ (Scenario 1), 50\% (Scenario 2), and 30\% (Scenario 3) of the recharge, respectively over the continent (Pavelic et al., 2013). 
Table 2. Irrigation efficiency dependent on irrigation cropping pattern zone (FAO, 1997).

\begin{tabular}{|c|c|c|}
\hline $\begin{array}{l}\text { Irrigation } \\
\text { cropping } \\
\text { pattern zone } \\
\text { Number }\end{array}$ & Zone name & $\begin{array}{l}\text { Irrigation } \\
\text { efficiency } \\
(\%)\end{array}$ \\
\hline 1 & Mediterranean coastal zone & 60 \\
\hline 2 & Sahara oases & 70 \\
\hline 3 & Semi-arid to arid savanna West-East Africa & 50 \\
\hline 4 & Semi-arid/arid savanna East Africa & 50 \\
\hline 5 & Niger/Senegal rivers & 45 \\
\hline 6 & Gulf of Guinea & 50 \\
\hline 7 & Southern Sudan & 50 \\
\hline 8 & Madagascar tropical lowland & 50 \\
\hline 9 & Madagascar highland & 50 \\
\hline 10 & Egyptian Nile and Delta & 80 \\
\hline 11 & Ethiopian highlands & 50 \\
\hline 12 & Sudanese Nile area & 80 \\
\hline 13 & Shebelli-Juba river area in Somalia & 50 \\
\hline 14 & Rwanda - Burundi - Southern Uganda highland & 50 \\
\hline 15 & Southern Kenya - Northern Tanzania & 50 \\
\hline 16 & Malawi - Mozambique - Southern Tanzania & 45 \\
\hline 17 & West and Central African humid areas & 45 \\
\hline 18 & Central African humid areas below equator & 45 \\
\hline 19 & Rivers effluents on Angola/Namibia/Botswana border & 50 \\
\hline 20 & South Africa - Namibia - Botswana desert \& steppe & 65 \\
\hline 21 & Zimbabwe highland & 60 \\
\hline 22 & South Africa - Lesotho - Swaziland & 60 \\
\hline 23 & Awash river area & 50 \\
\hline
\end{tabular}

Table 3. Other groundwater uses (adapted from Pavelic et al., 2013).

\begin{tabular}{|c|c|c|c|}
\hline \multicolumn{2}{|c|}{ Uses/unit } & Daily water & $\begin{array}{l}\text { Portion assumed } \\
\text { to come from } \\
\text { groundwater }(\%)\end{array}$ \\
\hline Domestic & Inhabitant & 50 & 75 \\
\hline Industrial & Inhabitant & 25 & 75 \\
\hline \multirow{4}{*}{ Livestock } & Big ruminant & 40 & 100 \\
\hline & Small ruminant & 20 & 100 \\
\hline & Pig & 30 & 100 \\
\hline & Poultry & 0.2 & 100 \\
\hline
\end{tabular}

\section{Calculation of groundwater irrigation potential}

The GWIP (Eq. 1) is calculated using the maximum annual estimate of irrigation water demand (Irrig. Water Demand) over the 1960-2000 period for each cell. Hence, a conservative estimate of the irrigation potential is obtained. However, rather than equally using the maximum values of groundwater availability (GW Available), a constant averaged annual value of this parameter was used. This in essence corresponds to smoothing out the variability in groundwater availability (and recharge) and accounting for the buffering ef- fect of the resource. Hence, in low groundwater availability years, regular water availability is assumed. If the average GW Available is negative in a cell (due to persistent low recharge years or high human and environmental demand), the availability is set to zero for that cell.

For the Irrig. Water Demand (Eq. 3), annual values were processed from aggregated monthly data of crop water demand for the individual crop groups within each cell, after reducing by available green water for each particular month. The share of each crop group within the crop group area is accounted for (\% of Area, Eq. 3). Since for each crop group, up to two specific crops can be grown in rotation on the same area but never concurrently (Supplement), the number of crops ( $n, \mathrm{Eq} .3)$ in this case refers to the number of crop groups, rather than specific crops. Similarly, the Crop Water Demand refers to the sum of the crop water demand of the actually grown crops in the crop group.

\section{Results}

The net irrigation water demand (Irrig. Water Demand $\times$ Irrig. Efficiency) is shown in Fig. 4. It is seen (Fig. 4a) that the irrigation demand reflects primarily the density of cropland (Fig. 1) and the aridity of the regions (Fig. 4b). It also reflects the green water availability, which is 
(a)

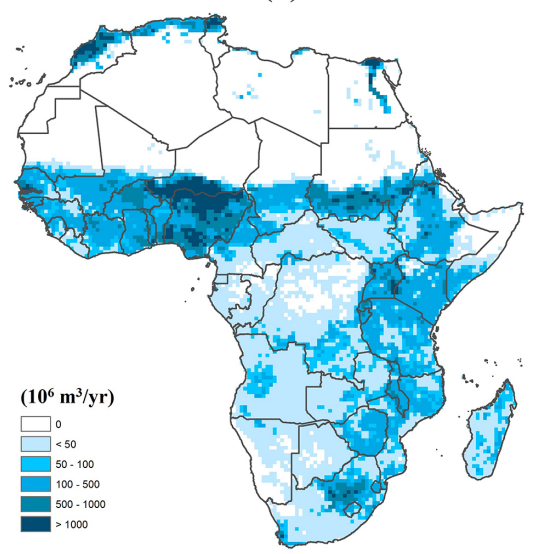

(b)

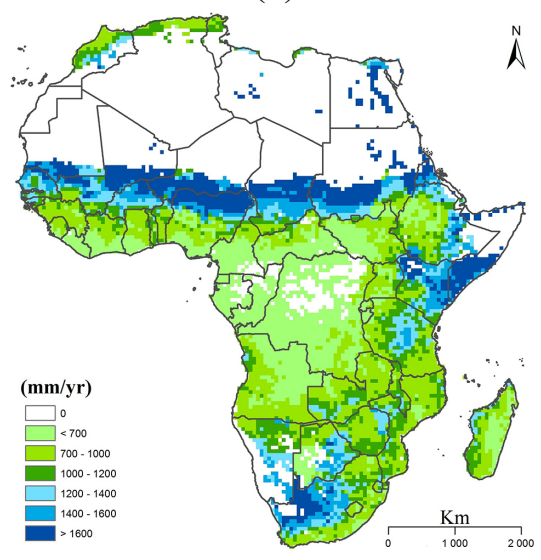

Figure 4. Estimated average net irrigation water demand (1960-2000) for the cropland in Fig. 1: (a) expressed in $10^{6} \mathrm{~m}^{3} \mathrm{year}^{-1} \mathrm{cell}^{-1}$ $\left(0.5^{\circ} \times 0.5^{\circ}\right)$ and $(\mathbf{b})$ in $\mathrm{mm}_{\text {year }}{ }^{-1}$.

higher in the equatorial regions, except in East Africa (Supplement).

The groundwater available for irrigation is the surplus recharge after satisfying human and environmental groundwater needs (Eq. 1). This varies according to the three scenarios (Fig. 5). The total renewable groundwater availability for irrigation across the continent ranges from 692 (Scenario 1) to $1644 \mathrm{~km}^{3}$ year $^{-1}$ (Scenario 3). Not surprisingly, the availability is greater along an equatorial band across the continent where rainfall and recharge are highest. It is also seen that large parts of northern and southern Africa are devoid of excess recharge to enable irrigation from renewable groundwater resources.

Converting the groundwater availability into GWIP in terms of irrigable area, a similar pattern is found (Fig. 6). The white areas in central Africa with zero potential correspond to areas with no cropland, essentially areas covered by permanent forest. Appreciable hydrological potential exists for GWI across much of Africa, except for the most arid regions and in the most southern part where demand from other sectors compete with GWI (data not shown). Hence, most regions in the Sahel and the eastern tract of the continent, from Ethiopia down to Zimbabwe, may provide significant unexploited opportunities for groundwater development for agriculture, with up to all cropland, and sometimes more, being irrigable from renewable groundwater. This benefit accrues from mostly supplementary GWI in the wet season as well as mostly full GWI in the dry season. The maps also indicate that relatively large disparities in GWIP exist within individual countries, e.g. Ethiopia, Mozambique, Angola and Tanzania. Potential hotspot areas should be further explored in terms of other factors governing the potential for GWI development. Aggregating the GWIP across the continent, values range from $44.6 \times 10^{6}$ ha to $105.3 \times 10^{6}$ ha for the three scenarios, corresponding to 20.5 to $48.5 \%$ of the cropland.
The GWIP for the 13 countries estimated by Pavelic et al. $(2013)\left(13.5 \times 10^{6} \mathrm{ha}\right)$ is here calculated to $17.1 \times 10^{6} \mathrm{ha}$, showing good correspondence between the methods, though the present method does indicate the distributed extent of GWIP across the countries and for the whole continent. In Table 4, the GWIP for the individual countries in Africa are given. The results show that the GWI area in Africa can safely be expanded by a factor of 20 or more, based on the conservative renewability and environmental requirements of the resource and the present human demands, possibly with wide livelihood benefits for smallholder farmers in many Sahel and semi-arid regions of eastern Africa. Comparing the GWIP with the overall irrigation potential of $42.5 \times 10^{6}$ ha estimated by FAO (2005), it is clear that groundwater can play a significant role in food production and food security in large parts of Africa. While in such comparison, figures for irrigation potential may not be simply additive due to overlap of the resources and lack of cropland or other constraints, it is clear that opportunities exist in the concurrent development of both sources and some benefits are achievable in planning schemes that are conjunctive (Evans et al., 2012).

Some blue areas with very high potential relative to the cropland area (Fig. 6i), as seen in arid parts of South Africa, Mali and Sudan can be explained by very small cropland areas relative to the cell size. Hence, accumulated recharge over the cell, albeit low in nominal terms, may be sufficient to irrigate these areas.

In order to further analyse the GWIP, and explore the untapped part of the potential, the results are compared with existing data on the present development of GWI across Africa (Fig. 7). The map in Fig. 7a presents the best available continent-wide data for areas equipped for GWI (Siebert et al., 2010), while Fig. 7b shows the relative GWIP (in terms of area) in Scenario 2 (the environmental groundwater requirements represent $50 \%$ of recharge), expressed as the percentage of the data from Siebert. While this approach only 
(a)

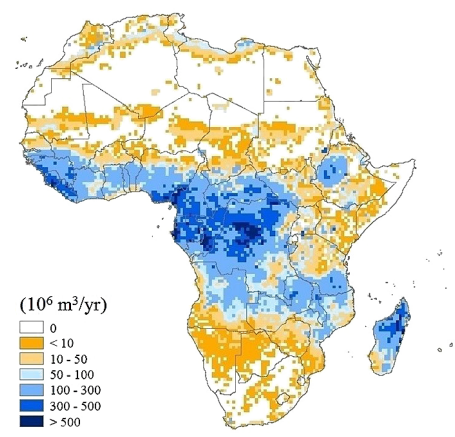

(b)

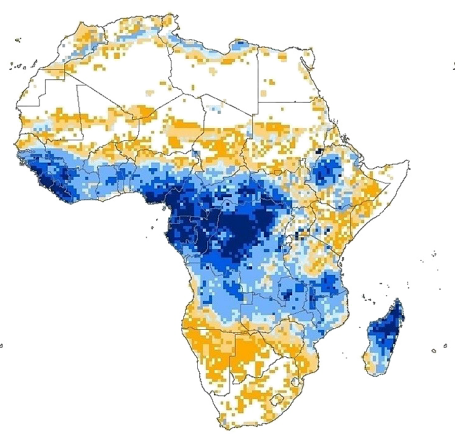

(c)

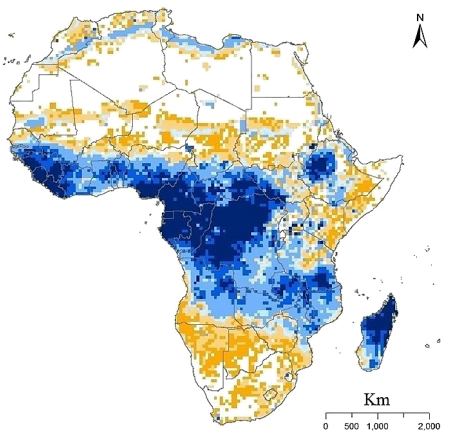

Figure 5. Average groundwater availability for irrigation (1960-2000), expressed in $10^{6} \mathrm{~m}^{3}$ year ${ }^{-1}$ cell ${ }^{-1}\left(0.5^{\circ} \times 0.5^{\circ}\right)$, for various levels of environmental groundwater requirements as a fraction of recharge: (a) Scenario 1: $70 \%$, (b) Scenario 2: 50 \%, (c) Scenario 3: $30 \%$.

(a)

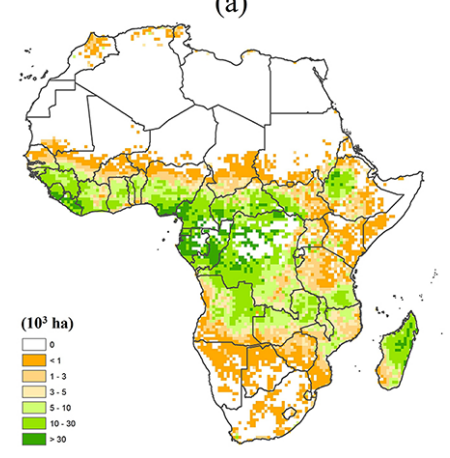

(a)

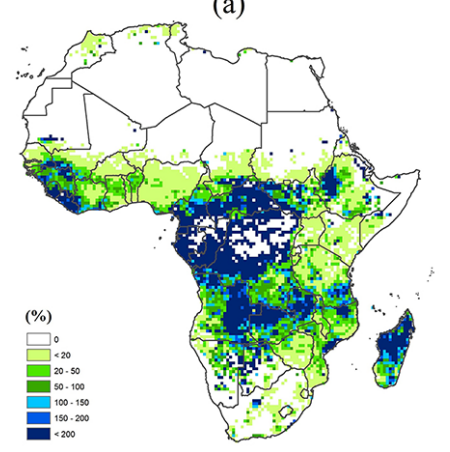

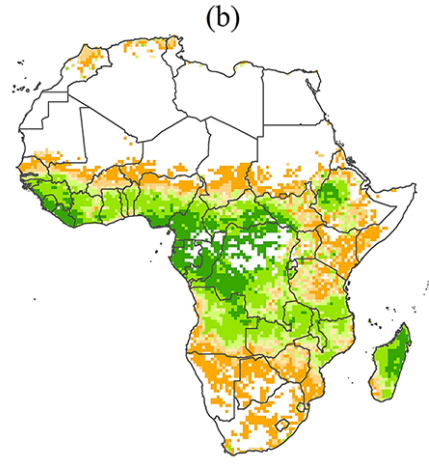

II

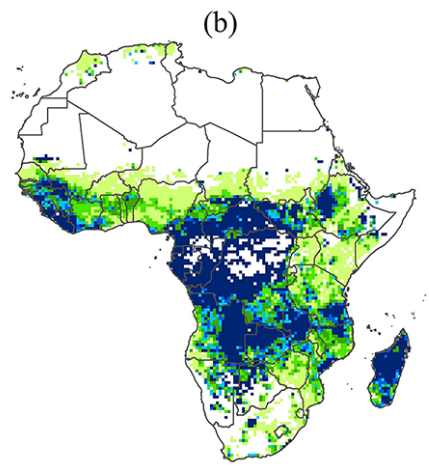

(c)

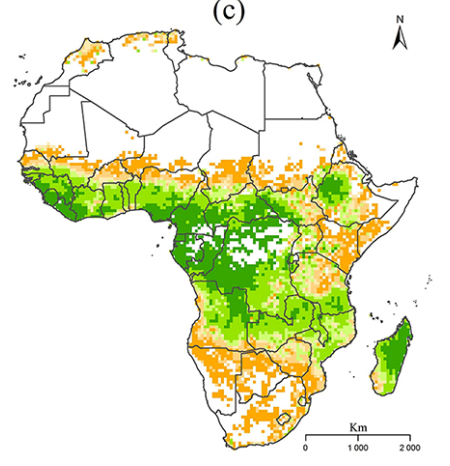

(c)

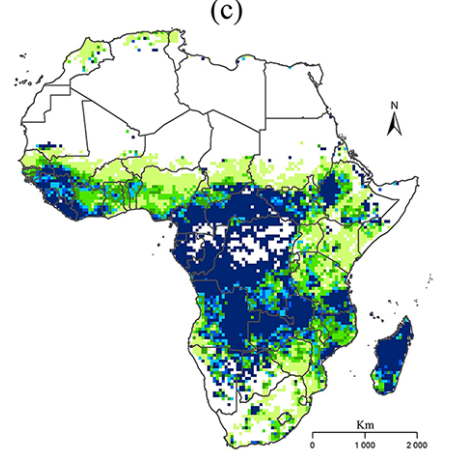

Figure 6. (I) Total area irrigable with groundwater inside a cell $\left(0.5^{\circ} \times 0.5^{\circ}\right)$ in $10^{3}$ ha and (II) proportion of cropland irrigable with groundwater, for various levels of environmental groundwater requirements as a fraction of recharge: (a) Scenario 1: $70 \%$, (b) Scenario 2: 50\%, (c) Scenario $3: 30 \%$.

captures and compares areas having non-negative values for present GWI development, it gives a clear indication of the contrast across the continent with respect to the areas with and without further GWIP (the non-red areas versus the red areas). In northern and southern Africa the untapped development potential is very limited or patchy, while in western Africa and the eastern belt, still appreciable GWI development potential exists. These results also indicate that presently GWI is mostly developed in regions with limited potential, and significantly in areas where groundwater is non-renewable (like in northern Africa) or where limited uncommitted renewable groundwater resources exist. In fact, the method also gave indications of where groundwater is already over-allocated, based only on the human needs (let alone irrigation and the environment) relative to the recharge. This is generally not the case, but occurrences appear in arid high-density livestock or populated parts of northeastern South Africa and southeastern North Sudan (data not 
Table 4. Gross groundwater irrigation potential and cultivated area per country in Africa.

\begin{tabular}{|c|c|c|c|c|c|}
\hline & \multicolumn{3}{|c|}{$\begin{array}{r}\text { Area of cropland } \\
\text { irrigable with } \\
\text { groundwater }{ }^{\mathrm{a}}\left(10^{3} \mathrm{ha}\right)\end{array}$} & $\begin{array}{l}\text { Siebert et } \\
\text { al. (2010) }\end{array}$ & $\begin{array}{r}\text { FAO }_{-} \\
\text {AQUASTAT }^{\mathrm{b}}\end{array}$ \\
\hline & \multicolumn{3}{|c|}{$\begin{array}{r}\text { Scenario (Percentage } \\
\text { of groundwater } \\
\text { for environmental } \\
\text { requirements) }\end{array}$} & $\begin{array}{r}\text { Area equipped } \\
\text { for irrigation } \\
\text { irrigated with } \\
\text { groundwater }\left(10^{3} \mathrm{ha}\right)\end{array}$ & $\begin{array}{r}\text { Cultivated } \\
\text { land }\left(10^{3} \text { ha) }\right.\end{array}$ \\
\hline & $1(30 \%)$ & $2(50 \%)$ & $3(70 \%)$ & & \\
\hline Algeria & 140 & 94 & 49 & 362.1 & 8465 \\
\hline Angola & 7032 & 5016 & 3001 & 16.0 & 5190 \\
\hline Benin & 518 & 368 & 218 & 2.2 & 3150 \\
\hline Botswana & 66 & 46 & 27 & 0.7 & 287 \\
\hline Burkina Faso & 268 & 188 & 108 & 3.0 & 6070 \\
\hline Burundi & 214 & 149 & 84 & 0.0 & 1450 \\
\hline Cameroon & 7019 & 5005 & 2990 & 1.0 & 7750 \\
\hline Central African Republic & 6961 & 4969 & 2978 & 0.0 & 1880 \\
\hline Chad & 566 & 401 & 237 & 6.0 & 4932 \\
\hline Côte d'Ivoire & 2920 & 2078 & 1236 & 0.0 & 7400 \\
\hline Democratic Republic of Congo & 23060 & 16450 & 9840 & 0.0 & 7810 \\
\hline Djibouti & 5 & 3 & 2 & 1.0 & 2 \\
\hline Egypt & 2 & 2 & 1 & 331.9 & 3612 \\
\hline Equatorial Guinea & 634 & 453 & 271 & 0.0 & 180 \\
\hline Eritrea & 10 & 7 & 4 & 16.2 & 692 \\
\hline Ethiopia & 4336 & 3064 & 1793 & 2.6 & 16488 \\
\hline Gabon & 5884 & 4202 & 2520 & 0.0 & 495 \\
\hline Gambia & 24 & 17 & 10 & 0.0 & 445 \\
\hline Ghana & 1426 & 1010 & 594 & 12.0 & 7400 \\
\hline Guinea & 2751 & 1962 & 1172 & 0.5 & 3700 \\
\hline Guinea-Bissau & 176 & 125 & 75 & 4.9 & 550 \\
\hline Kenya & 512 & 355 & 199 & 1.0 & 6130 \\
\hline Lesotho & 21 & 15 & 8 & 0.1 & 285 \\
\hline Liberia & 2238 & 1597 & 956 & 0.0 & 710 \\
\hline Libya & 26 & 18 & 10 & 464.0 & 2055 \\
\hline Madagascar & 6753 & 4814 & 2875 & 0.0 & 4110 \\
\hline Malawi & 640 & 454 & 268 & 0.0 & 3885 \\
\hline Mali & 787 & 559 & 331 & 1.0 & 7011 \\
\hline Mauritania & 52 & 37 & 22 & 4.8 & 411 \\
\hline Morocco & 145 & 97 & 49 & 677.2 & 9403 \\
\hline Mozambique & 2171 & 1546 & 921 & 0.6 & 5950 \\
\hline Namibia & 98 & 70 & 41 & 1.6 & 809 \\
\hline Niger & 19 & 12 & 6 & 1.4 & 16000 \\
\hline Nigeria & 6287 & 4446 & 2606 & 66.8 & 41700 \\
\hline Republic of Congo & 7420 & 5295 & 3170 & 0.0 & 600 \\
\hline Rwanda & 148 & 102 & 56 & 0.1 & 1432 \\
\hline Senegal & 382 & 271 & 160 & 10.2 & 3415 \\
\hline Sierra Leone & 1551 & 1107 & 662 & 0.2 & 1897 \\
\hline Somalia & 51 & 35 & 20 & 10.0 & 1129 \\
\hline South Africa & 270 & 181 & 95 & 127.3 & 12413 \\
\hline South Sudan & 3042 & 2164 & 1286 & 0.2 & $2760^{\mathrm{c}}$ \\
\hline Sudan & 429 & 299 & 169 & 69.0 & $13893^{\mathrm{c}}$ \\
\hline Swaziland & 21 & 15 & 8 & 1.0 & 190 \\
\hline Tanzania & 3007 & 2135 & 1263 & 17.5 & 16650 \\
\hline Togo & 300 & 213 & 126 & 0.1 & 2850 \\
\hline Tunisia & 26 & 17 & 9 & 257.0 & 5249 \\
\hline Uganda & 571 & 399 & 228 & 0.1 & 9150 \\
\hline Western Sahara & 0 & 0 & 0 & 0.0 & $4^{\mathrm{c}}$ \\
\hline Zambia & 3952 & 2818 & 1684 & 6.7 & 3836 \\
\hline Zimbabwe & 370 & 259 & 148 & 20.0 & 4100 \\
\hline
\end{tabular}

a Errors up to $35 \%$ for small countries (due to the cell size, the projection used in GIS and the shape of the countries, i.e. Gambia);

${ }^{\mathrm{b}}$ http://www.fao.org/nr/water/aquastat/countries_regions/index.stm; ${ }^{\mathrm{c}}$ estimated. 
(a)

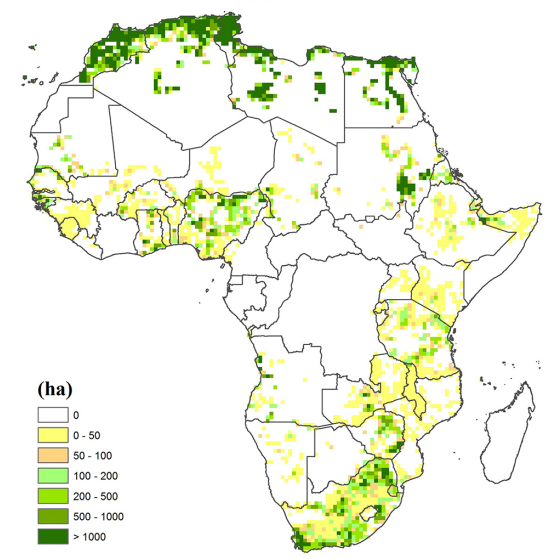

(b)

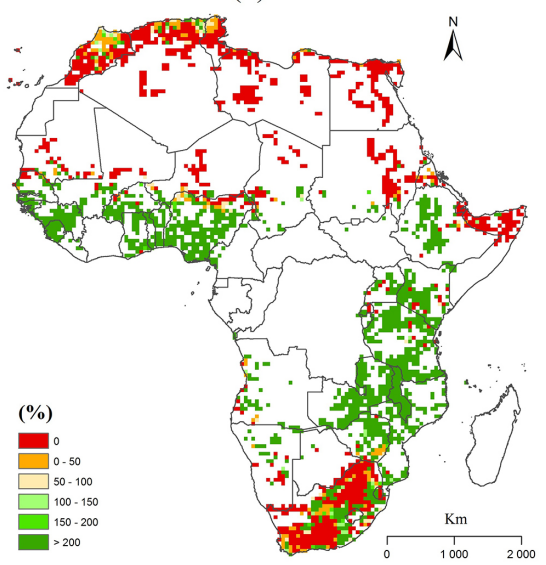

Figure 7. (a) Area irrigated with groundwater in 2005 expressed in ha. per cell adapted from Siebert et al. (2010) and (b) groundwater irrigation potential for Scenario 2 (the environmental groundwater requirements represent $50 \%$ of the recharge) for the year 2000 expressed as the percentage of the area irrigated with groundwater in 2005.

Table 5. Comparison of estimations of groundwater recharge for selected African countries.

\begin{tabular}{lrrr}
\hline \multirow{2}{*}{ Country } & \multicolumn{3}{c}{${\text { Recharge }\left(\mathrm{mm} \mathrm{year}^{-1}\right)}$} \\
\cline { 2 - 4 } & FAO, & $\begin{array}{r}\text { Döll and } \\
\text { AQUAStat }(2009)^{\mathrm{a}}\end{array}$ & $\begin{array}{r}\text { This } \\
\text { paper }^{\mathrm{c}}\end{array}$ \\
\cline { 2 - 4 } Fiedler $(2008)^{\mathrm{b}}$ & 39 & 39 \\
Burkina Faso & 34.6 & 39 & 80 \\
Ghiopia & 18.1 & 105 & 127 \\
Kenya & 110.3 & 46 & 29 \\
Malawi & 6.0 & 164 & 170 \\
Mali & 21.1 & 22 & 23 \\
Mozambique & 16.1 & 104 & 82 \\
Niger & 21.3 & 12 & 4 \\
Nigeria & 2.0 & 163 & 154 \\
Rwanda & 94.2 & 68 & 78 \\
Tanzania & 265.8 & 93 & 90 \\
Uganda & 31.7 & 95 & 50 \\
Zambia & 122.9 & 108 & 117 \\
\hline a http://www.fao.org/nr/water/aquastat/main/index.stm (last accessed: 2 April 2014). \\
b Data as provided in Margat and Gun (2013). ${ }^{{ }^{c}}$ Data calculated from the \\
PCR-GLOBWB model (Van Beek et al., 2011).
\end{tabular}

shown). An apparent artefact is discernible in the horn of Africa. Here, appreciable GWI exists (Fig. 7a), while Fig. 1 shows no cropland. The explanation could be that areas in this region are mostly irrigated pasture land, or pasture land converted into irrigated cropland after the 2000 map of cropland (Fig. 1) was produced.

\section{Discussion}

\subsection{Uncertainty and variability of recharge and environmental requirements}

In assessing the confidence of the methodology presented, the uncertainty and temporal variability of recharge as well as the uncertainty of the environmental requirements need to be taken into consideration. Table 5 summarizes estimations of groundwater recharge for a number of African countries from different sources. It shows that the annual recharge estimation from the hydrological model PCR-GLOBWB (this paper) is quite similar to the one estimated from the WaterGAP Global Hydrology Model (WGHM) (Döll and Fiedler, 2008) while there is more discrepancy with the FAO data set. Since the GWIP is strongly dependent on the recharge, this uncertainty will be reflected in the GWIP.

The maps in Fig. 8 present the average annual recharge (Fig. 8a) and the coefficient of variation of the recharge (Fig. 8b) of the 41-year simulation period. The coefficient of variation shows clearly that the areas where the recharge is smaller (say less than $50 \mathrm{~mm}$ per year) also have the highest variability over the years. In these areas, recharge can vary from zero to double of the average recharge (dark red colour). The results indicate that where groundwater recharge is sufficient to support GWI in these areas, it is likely to be a very strategic resource in buffering seasonal and inter-annual climate variability. Secondly, the actual buffering capacity of groundwater, which is governed by the longer-term storage capacity of the aquifers, more so than the recharge, becomes equally important in these areas and needs to be addressed in further and more detailed assessments. In the present approach, buffering of the groundwater is only considered by using the long-term average GW Available in Eq. (1), as explained in the Sect. 4. Similarly, the buffering capacity of 
(a)

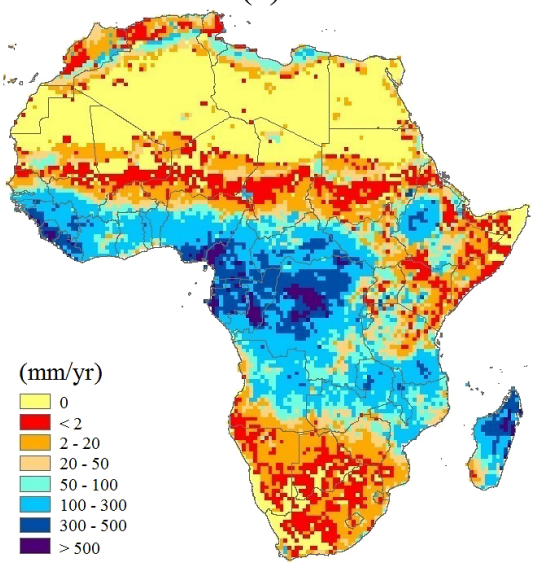

(b)

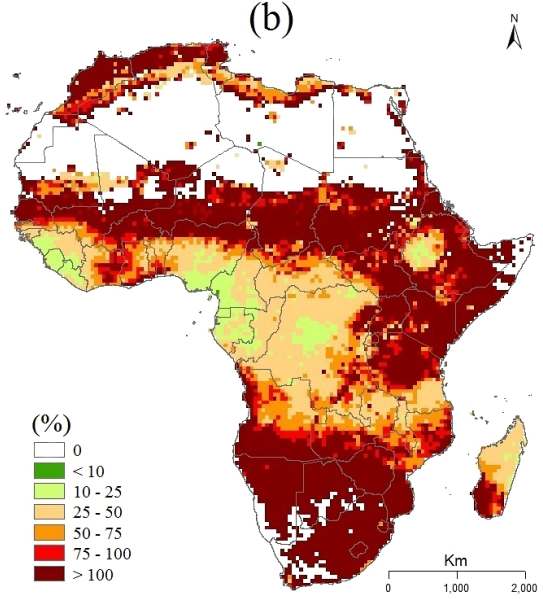

Figure 8. Average annual recharge $\left(\mathrm{mm} \mathrm{year}^{-1}\right)$ and (b) its coefficient of variation (\%), both over the period 1960-2000 (data from Van Beek et al., 2011).

Table 6. Aggregated groundwater available $\left(\mathrm{km}^{3} \mathrm{year}^{-1}\right)$ for the three environmental scenarios.

\begin{tabular}{rrrrrrrrr}
\hline & Scenario 1 & \multicolumn{3}{c}{ Scenario 2 } & \multicolumn{3}{c}{ Scenario 3 } \\
\hline Min.* $^{*}$ & Average & Max.* $^{*}$ & Min. & Average & Max. & Min. & Average & Max. \\
442.2 & 692.1 & 990.1 & 751.1 & 1168.3 & 1664.9 & 1006.1 & 1644.5 & 2339.7 \\
\hline
\end{tabular}

* Min. and Max. refers to minimum and maximum annual values over the 41 years.

groundwater in a spatial sense was applied in assuming that all recharge in a cell can be captured anywhere in that cell.

The uncertainty associated with the environmental requirements relates to the lack of knowledge of the location and functioning of ecosystems dependent on groundwater throughout Africa and their groundwater requirements in quantitative terms. Such ecosystems and their requirements may depend on the hydrogeological setup of an area, the scale of the aquifers, and the climate (Tomlinson, 2011). However, in the absence of better understanding and tested approaches, the three scenarios approach was used (Pavelic et al., 2013). When comparing the uncertainty related to the scenarios in terms of the GW Available (Table 6) (about $480 \mathrm{~km}^{3}$ year ${ }^{-1}$, as calculated from the difference between the averages of Scenario 2 and 1, and Scenario 2 and 3, respectively), and the uncertainty related to the recharge (estimated from the range between the average and min. and average and max. annual GW Available for Scenario 2, which is 417 and $496 \mathrm{~km}^{3}$ ) it is apparent that the uncertainty on groundwater availability related to the environmental requirements is of the same order of magnitude as the effect of the temporal variability of recharge.

\subsection{Limitations of approach}

The water balance approach considers locally renewable groundwater availability as the major controlling parameter for GWIP and assumes non-limiting conditions in terms of other fundamental physical properties, e.g. soil and water quality, terrain slope, and groundwater accessibility (as determined by e.g. depth of the usable aquifer, storage available for recharge, and well yields) for the implementation of GWI. Considering an average landholding size of 1 ha with a single well, or alternatively 1 well per hectare for landholdings larger than 1 ha, over the continent and the gross irrigation water demand per year varying between 235 and $3000 \mathrm{~mm}$ per year, with the cropping pattern applied in the present study, an average cropping season of 240 days of daily irrigation for $8 \mathrm{~h}$, this translates into a required well yield varying from 0.3 to $4.3 \mathrm{~L} \mathrm{~s}^{-1}$. Comparing this with continental-wide maps of well yields (MacDonald et al., 2012), it is evident that in certain geological formations, like the basement rock aquifers, that occupy $34 \%$ of the continent (Adelana and MacDonald, 2008), the yield of the geological substrata may in places be limiting for larger scale or very intensive GWI development.

The GWIP was conceived strictly in terms of the quantitative availability of renewable groundwater. Possible constraints related to hydrogeology as well as water quality and socioeconomic conditions, such as infrastructure (roads, markets, energy/electricity) or intuitional/farmer capacities may further reduce this potential or hamper its realization as will be further analysed in a companion paper. Rapid assessment of borehole yields indicated a possible limitation 
due to the hydrogeological transmitting properties in certain regions.

Furthermore, climate trends and progressive water demands from growing human and livestock populations have not been considered. For these reasons, it is suggested to apply the most conservative estimates (i.e. Scenario 1) for a robust estimate of hydrological GWIP. Likewise, historic and potential future changes in cropping patterns and irrigation efficiencies have not been considered though they could significantly enhance the groundwater availability, through increasing the green water availability (by shifting the unproductive part to productive), and hence the potential for irrigation. In essence, the method is a snapshot continental distributed view of present or most recent GWIP, based on averaged hydrological conditions and best available most recent coherent data sets. However, the influence of cropping choice was clearly demonstrated in Pavelic et al. (2013). They showed that going from a $1000 \mathrm{~mm}$ year $^{-1}$ irrigation demand to a $100 \mathrm{~mm}$ year $^{-1}$ crop, everything else being equal, entailed an order of magnitude higher GWIP.

\section{Conclusions}

The present study has estimated the extent and distribution of groundwater irrigation potential (GWIP) across the African continent $\left(0.5^{\circ}\right.$ resolution), based on the hydrologically available and renewable groundwater over a 41-year recent historic period and using crop and cropland data from the beginning of the century. The GWIP is assessed to be between $44.6 \times 10^{6}$ ha and $105.3 \times 10^{6}$ ha, depending on the proportion of recharge assumed allocated preferentially to the environment (30-70\%), while assuming constant human needs for groundwater. This is a gross estimate, disregarding existing groundwater irrigation (GWI). However, with the present GWI area amounting to approximately $2 \times 10^{6}$ ha, the difference between net and gross potential is small. However, comparing GWIP to existing maps of GWI, it is clear that present GWI has been primarily developed in northern and southern Africa where the development potential is relatively limited, and where it is governed by abstraction from non-renewable or already stressed resources, from recharge from larger rivers like the Nile, or return flows from surface water schemes, while the rest of the continent (except for the Sahara region) still has appreciable potential, especially and most relevantly for smallholder and less intensive GWI in the semi-arid Sahel and east Africa regions. This could significantly increase the food production and productivity in the region from a reliable and renewable resource.

\section{The Supplement related to this article is available online at doi:10.5194/hess-19-1055-2015-supplement.}

Acknowledgements. Rens Van Beek, Geosciences - Utrecht University, kindly provided data from the PCR-GLOBWB model. Agnès Ducharne, Laboratoire METIS - Université Pierre et Marie Curie - Paris, provided critical view, specifically on Crop Water Demand. The work has been partially funded by the French Ministry of Agriculture and by USAID (Enhanced Regional Food Security through Increased Agricultural Productivity to Sustainably Reduce Hunger project of the USAID Southern Africa Feed The Future (FTF) programme (2012-2013)). It was also supported by CGIAR Strategic Research Program on Water, Land and Ecosystems (WLE).

Edited by: M. Vanclooster

\section{References}

Adelana, S. M. A. and MacDonald, A. M.: Groundwater research issues in Africa, in: Applied Groundwater Studies in Africa, edited by: Adelana, S. M. A. and MacDonald, A. M., IAH Selected Papers on Hydrogeology, no. 13, Ch. 1, CRC Press, Taylor \& Francis Group, London, UK, 507 pp., 2008.

Awulachew, S. B., Erkossa, T., and Namara, R. E.: Irrigation Potential in Ethiopia - Constraints and Opportunities for Enhancing the System, International Water Management Institute, available at: http://www.ata.gov.et/wp-content/uploads/ Ethiopia-Irrigation-Diagnostic-July-2010.pdf (last access: 20 May 2014), 59 pp., 2010.

CAADP (Comprehensive African Agriculture Development Programme): Sustainable Land and Water Management, The CAADP Pillar I Framework, available at: http://www.caadp.net/ pdf/CAADPPillar1Framework.pdf (last access: 21 May 2014), 76 pp., 2009.

Döll, P. and Fiedler, K.: Global-scale modeling of groundwater recharge, Hydrol. Earth Syst. Sci., 12, 863-885, doi:10.5194/hess-12-863-2008, 2008.

Evans, W. R., Evans, R. S., and Holland, G. F.: Conjunctive use and management of groundwater and surface water within existing irrigation commands: the need for a new focus on an old paradigm. Thematic Paper 2. Groundwater Governance: A Global Framework for Country Action, GEF ID 3726, 48 pp, 2012.

Falkenmark, M. and Rockström, J.: The new blue and green water paradigm: Breaking new ground for water resources planning and management, J. Water Resour. Plann. Manage., 132, 129132, 2006.

FAO: Irrigation Water Management: Irrigation Water Need, Training Manual no. 3, edited by: Brouwer, C. and Heibloem, M., Food and Agriculture Organization of United Nations, Rome, Italy, 102 pp., 1986.

FAO: Irrigation Water Management: Irrigation Scheduling, Training Manual no. 4, edited by: Brouwer, C., Prins, K., and Heibloem, M., Food and Agriculture Organization of United Nations, Rome, Italy, Land and Water Development Division, 66 pp., 1989.

FAO: Crop Water Requirements, FAO Irrigation and Drainage Paper no. 24, edited by: Doorenbos, J., Pruitt, 5 W. O., Aboukhaled, A., Damagnez, J., Dastane, N. G., Van den Berg, C., Rijtema, P. E., Ashford, O. M., and Frere, M., Food and Agriculture Organization of United Nations, Land and Water Development Division, Rome, Italy, 144 pp., 1992. 
FAO: Irrigation Potential in Africa: a Basin Approach, FAO Land and Water Bulletin 4, Food and Agriculture Organization of United Nations, Land and Water Development Division, Rome, Italy, 177 pp., 1997.

FAO: Irrigation in Africa in Figures, AQUASTAT Survey - 2005, FAO Water Reports no. 29, Food and Agriculture Organization of the United Nations, Rome, available at: ftp://ftp.fao.org/ agl/aglw/docs/wr29_eng.pdf (last access: 20 May 2014), 74 pp., 2005.

FAO: Population density (persons/km2), available at: http://www.fao.org/geonetwork/srv/en/resources.get?id= 30586\&fname=poprecl_ASCII.zip\&access=private (last access: 31 March 2014), 2007a.

FAO: Gridded livestock of the world, available at: http://www.fao. org/ag/againfo/resources/en/glw/GLW_dens.html (last access: 31 March 2014), 2007b.

Foster, S. and Perry, C.: Improving groundwater resource accounting in irrigated areas: a prerequisite for promoting sustainable use, Hydrogeol. J., 18, 291-294, 2010.

MacDonald, A. M., Calow, R. C., Nicol, A. L., Hope, B., and Robins, N. S.: Ethiopia: water security and drought, Technical Report WC/01/02, British Geological Survey, Nottingham, available at: http://nora.nerc.ac.uk/501045/1/Ethiopia_map.pdf (last access: 20 May 2014), 2001.

MacDonald, A. M., Bonsor, H. C., Dochartaigh, B. É. Ó., and Taylor, R. G.: Quantitative maps of groundwater resources in Africa, Environ. Res. Lett., 7, 024009, doi:10.1088/17489326/7/2/024009, 2012.

Margat, J. and Van der Gun, J.: Groundwater Around the World: a Geographic Synopsis, CRC Press, Taylor \& Francis Group, London, UK, 376 pp., 2013.

MoAC (Ministry of Agriculture and Co-operatives): The Republic of Zambia: National Agriculture Policy 2004/2015, 54 pp., available at: http://www.gafspfund.org/sites/gafspfund.org/files/ Documents/5.Zambia_strategy.pdf (last access: 4 April 2014), 2004.

MoFED (Ministry of Finance and Economic Development): The Federal Democratic Republic of Ethiopia: Growth and Transformation Plan (GTP) 2010/11-2014/15 Draft, September 2010, Addis Ababa, 85 pp., 2010.

MoFA and GIDA (Ministry of Food and Agriculture and Ghana Irrigation Development Authority): National Irrigation Policy, Strategies and Regulatory Measures, GIDA, Accra, available at: http://mofa.gov.gh/site/wp-content/uploads/2011/07/ GHANA-IRRIGATION-DEVELOPMENT-POLICY1.pdf (last access: 20 May 2014), 37 pp., 2011.

MoIWD (Ministry of Irrigation and Water Development): The Republic of Malawi: National Water Policy, Lilongwe, available at: http://www.moafsmw.org/KeyDocuments/ NationalWaterPolicyFINAL.pdf (last access: 4 April 2014), 2005.

MoWEA (Ministry of Water and Environmental Affairs): The Republic of South Africa: National Water Resource Strategy, Department of Water Affairs, available at: http://www.dwaf.gov.za/nwrs/LinkClick.aspx?fileticket=u qFQycClbI\%3d\&tabid=91\&mid=496 (last access: 4 April 2014), 2013.
Monfreda, C., Ramankutty, N, and Foley, J. A.: Farming the planet: 2. Geographic distribution of crop areas, yields, physiological types, and net primary production in the year 2000, Global Biogeochem. Cy., 22, GB1022, doi:10.1029/2007GB002947, 2008.

NEPAD (New Partnership for Africa's Development): Comprehensive Africa Agriculture Development Programme, available at: http://www.nepad.org/system/files/caadp.pdf (last access: 20 May 2014), 102 pp., 2003.

Pavelic, P., Smakhtin, V., Favreau, G., and Villholth, K. G.: Waterbalance approach for assessing potential for smallholder groundwater irrigation in Sub-Saharan Africa, Water SA, 38, 399-406, doi:10.4314/wsa.v38i3.5, 2012.

Pavelic, P., Villholth, K. G., Smakhtin, V., Shu, Y., and Rebelo, L. M.: Smallholder groundwater irrigation in Sub-Saharan Africa: country-level estimates of development potential, Water Int., 38 , 392-407, doi:10.1080/02508060.2013.819601, 2013.

Portmann, F. T., Siebert, S. and Döll1, P.: MIRCA2000 - Global monthly irrigated and rainfed crop areas around the year 2000: A new high-resolution data set for agricultural and hydrological modelling, Global Biochem. Cy., 24, GB1011, doi:10.1029/2008GB003435, 2010.

Ramankutty, N., Evan, A., Monfreda, C., and Foley, J.: Farming the planet: 1. Geographic distribution of global agricultural lands in the year 2000, Global Biogeochem. Cy., 22, GB1003, doi:10.1029/2007GB002952, 2008.

Savenije, H. H. G.: The importance of interception and why we should delete the term evapotranspiration from our vocabulary, Hydrol. Process., 18, 1507-1511, 2004.

Siebert, S., Burke, J., Faures, J. M., Frenken, K., Hoogeveen, J., Döll, P., and Portmann, F. T.: Groundwater use for irrigation - a global inventory, Hydrol. Earth Syst. Sci., 14, 1863-1880, doi:10.5194/hess-14-1863-2010, 2010.

Tomlinson, M.: Ecological Water Requirements of Groundwater Systems: a Knowledge and Policy Review, Waterlines Report Series No. 68, National Water Commission, Canberra, Australia, December 2011, 134 pp., 2011.

Van Beek, L. P. H., Wada, Y., and Bierkens, M. F. P.: Global monthly water stress: I. Water balance and water availability, Water Resour. Res., 47, W07517, doi:10.1029/2010WR009791, 2011.

Villholth, K. G.: Groundwater irrigation for smallholders in Sub-Saharan Africa - a synthesis of current knowledge to guide sustainable outcomes, Water Int., 38, 369-391, doi:10.1080/02508060.2013.821644, 2013.

Wada, Y., Van Beek, L, Viviroli, D., Dürr, H., Weingartner, R., and Bierkens, M.: Global monthly water stress: 2. Water demand and severity of water stress, Water Resour. Res., 47, W07517, doi:10.1029/2010WR009792, 2011.

You, L., Ringler, C., Nelson, G., Wood-Sichra, U., Robertson, R., Wood, S., Guo, Z., Zhu, T., and Sun, Y.: What Is the Irrigation Potential for Africa? A Combined Biophysical and Socioeconomic Approach, IFPRI Discussion Paper 00993, June 2010, IFPRI, available at: http://www.ifpri.org/sites/default/files/ publications/ifpridp00993.pdf (last access: 20 May 2014), 2010. 